DOI: $10.34185 / 1991-7848 . i t m m .2020 .01 .005$

\title{
ДОСЛІДЖЕННЯ ДИНАМІЧНИХ ВЛАСТИВОСТЕЙ ЧАСТОТНО-РЕГУЛЬОВАНОГО ЕЛЕКТРОПРИВОДА МЕХАНІЗМУ ПЕРЕСУВАННЯ ЕЛЕКТРОДІВ ДУГОВОЇ ЕЛЕКТРОПЕЧІ ШЛЯХОМ МАТЕМАТИЧНОГО МОДЕЛЮВАННЯ
}

Куваєв В.Ю. ст. викл., Нежурін В.І. доц., канд.техн.наук, Стьопкін В.В. доц., канд.техн.наук, Кривицький Є.П. студент групи АП01-15М Національна металургійна академія України, м. Дніпро, Україна Аннотація. Considered literature devoted to the modernization of control systems, controllers and variable-frequency drive mechanism for movement of the electric arc furnace electrodes. The research of current and proposed drives through mathematical modeling. Models of the control system of the electrode mechanism for the basic and proposed variants with scalar and vector control are made in the MATLAB software. Survey on simulation models confirmed that the system provides vector control speed transient time 16\% less than the DC system and a static error is $0 \%$ to $3 \%$. The implementation of the electric drive of the mechanism of movement of electrodes based on the frequency converter with vector control and an induction motor is a promising direction of modernization.

Ключові слова: ПЕРЕТВОРЮВАЧ ЧАСТОТИ, АСИНХРОННИЙ ДВИГУН, ДУГОВА ЕЛЕКТРОПІЧ, СИСТЕМА АВТОМАТИЧНОГО РЕГУЛЮВАННЯ, РЕГУЛЯТОР, ПЕРЕХІДНІ ПРОЦЕСИ, МАТЕМАТИЧНА МОДЕЛЬ, СКАЛЯРНЕ КЕРУВАННЯ, ВЕКТОРНЕ КЕРУВАННЯ.

Вступ. Дугові сталеплавильні печі (ДСП) широко застосовуються в чорній металургії України для виробництва легованих сталей і сплавів. Основною вимогою до систем автоматичного регулювання (САР) режимів роботи ДСП та іх електроприводів $\epsilon$ необхідність якісної стабілізації електричного режиму на кожній технологічній стадії процесу плавки [1]. Автоматичні регулятори дугових печей реагують на відхилення повного опору фази від заданого значення.

Основний матеріал. Відомі літературні джерела, зокрема [2], які присвячені модернізації системи керування автоматичних регуляторів АРДМТ-Т, мають на меті детальний аналіз недоліків та переваг системи 
Ministry of Education and Science of Ukraine

The National Metallurgical Academy of Ukraine, Dnipro, 17 - 19 March, 2020

керування регуляторами, пропонують напрями модернізації діючих регуляторів за рахунок введення додаткових блоків, параметри яких аналітичними або кореляційними відношеннями пов'язані з електричними та технологічними режимами роботи дугових електропечей, приводять алгоритми дії та принципи програмування цих систем керування. Дослідження виконані за допомогою математичного моделювання, основною метою приведених розробок є побудова оптимальних систем керування діючими регуляторами 3 метою підвищення техніко-економічних показників виробництва продукції. Можливість використання частотно-регульованого приводу механізму пересування електродів в загальному вигляді проаналізовано в роботі [3], де доцільність його використання обгрунтовано 3 точки зору енергозбереження засобами електроприводу. В роботі [4] вважають, що особливістю ДСП як об’єктів керування є надто складний математичний опис режимів і безперервні випадкові зміни параметрів, що не дає змоги на основі класичної теорії автоматичного керування реалізувати оптимальні та адаптивні до зміни параметрів закони руху електродів. В роботі [4] ставиться задача комплексного дослідження показників динаміки діючого привода ДСП-200, електротехнологічної ефективності та електромагнітної сумісності. Однак нам не вдалося знайти матеріали, присвячені дослідженню та порівняльному аналізу динамічних властивостей привода пересування електродів дугової печі на основі системи ТП-Д з регулятором АРДМ-Т та привода по системі ПЧ-АД.

Метою даної роботи є детальна розробка структурної та функціональної схеми привода механізму пересування електродів 3 автоматичним регулятором на прикладі ДСП-3 фасоно-ливарного цеху ДМЗ на основі використання сучасних перетворювачів частоти, складання математичної моделі діючого привода та запропонованого, порівняльний аналіз якості системи керування приводом, виконаним за системою ТП-Д (постійний струм) та ПЧ-АД.

В якості приводного запропоновано асинхронний двигун 6АMУ100SP та частотний перетворювач VFD22C43A, який дозволяє реалізувати як скалярне, так i векторне керування приводом. Моделі системи керування електроприводом механізму пересування електродів ДСП-3 для базового та запропонованого варіантів зі скалярним та векторним керуванням виконані у програмному продукті MATLAB (у підпрограмі SIMULINK), результати 
International scientific and technical conference Information Technologies in Metallurgy and Machine building - ITMM 2020

моделювання наведені на рисунку 1 та проаналізовані 3 точки зору якості системи керування.

При дослідженні системи регулювання швидкості ТП-Д були розглянуті два варіанти. У першому варіанті система підлеглого регулювання швидкості мала два контури: контур струму 3 П-регулятором і контур швидкості 3 П-регулятором. У другому варіанті: контур струму з ПІ-регулятором і контур швидкості 3 П-регулятором. Вибір зроблений на двоконтурній системі регулювання швидкості 3 зовнішнім контуром швидкості (пропорційний регулятор) i підпорядкованим йому контуром струму (ПІ-регулятор). На рисунку 1,а,б,в: - завдання на швидкість; 2 - швидкість; 3 - струм у відносних одиницях.

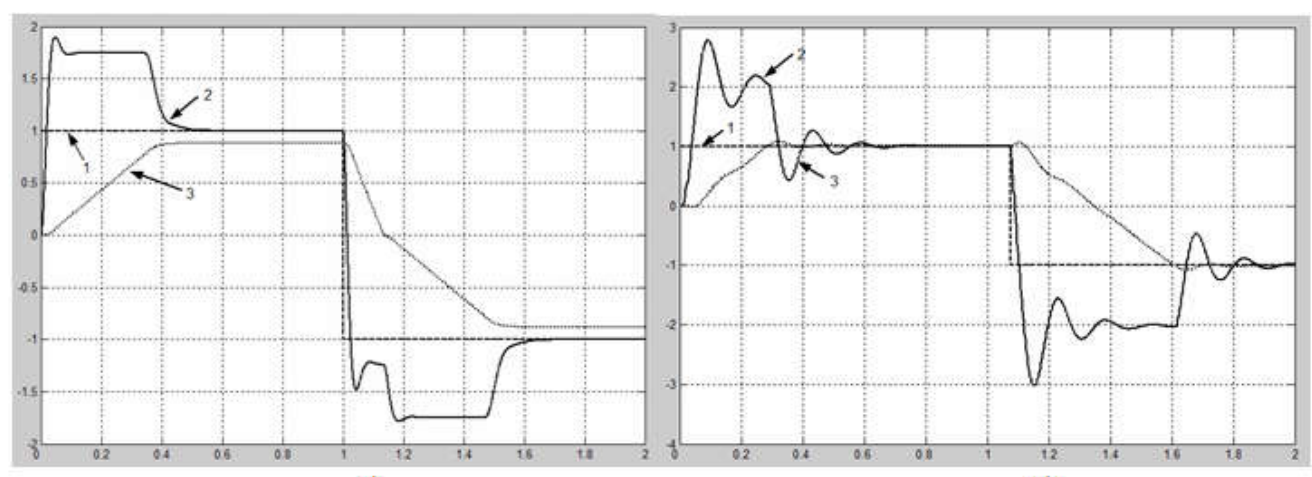

a)

б)

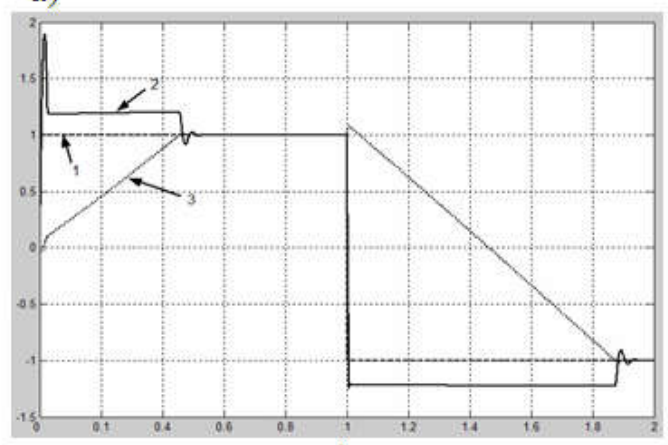

B)

Рисунок 1- Графіки перехідних процесів за струмом та швидкістю:

а) - система ТП-Д; б) - скалярна система; в) - векторна система

На моделі привода 3 векторним керуванням розділені канали керування швидкістю та потокозчепленням. Об’єкт керування характеризується наявністю нелінійних перехресних зв’язків між каналами керування. Для їх компенсації у систему автоматичного регулювання введено нелінійні зв’язки, що відтворюють функціональні залежності, зворотні залежностям об’єкта керування. Цим забезпечено задані динамічні характеристики системи автоматичного регулювання, а також, в деяких випадках, i ï̈ стійкість. Дослідження на імітаційній моделі підтвердило, що привод по системі ПЧ-АД з 
векторним регулюванням швидкості забезпечує час перехідних процесів на 16\% менше, ніж система ТП-Д, а статична помилка складає 0 \% проти 3\%

На отриманих графіках зміни швидкості видно, що після розгону двигуна привода, швидкість обертання залишалася незмінною до моменту подачі електрода у ванну. При збільшенні моменту навантаження відбувається невелике зниження обертів та триває певний час, по закінченні якого швидкість двигуна вертається до номінального значення. Дана схема дозволяє змінювати швидкість двигуна до й після зміни навантаження, дозволяє змінювати всі інтервали часу, тобто дозволяє повністю контролювати всі зміни й задавати їх, що вказує на працездатність системи i iï відповідність пропонованим вимогам. На основі аналізу технологічного процесу, алгоритму роботи електропривода механізму пересування електродів печі було складено функціональна схема автоматизації по системі ПЧ-АД. Таким чином, розроблена система може бути використана для керування електроприводом механізму пересування електродів ДСП - 3.

Висновки. Реалізація електроприводу механізму пересування електродів ДСП-3 на основі частотного перетворювача 3 векторним керуванням та асинхронного двигуна $є$ достатньо перспективним напрямом модернізації i, як показали дослідження 3 використанням математичного моделювання, дозволяє підвищити швидкодію привода, зменшивши час перехідних процесів на 16\%, а, відповідно, зменшити втрати енергії при перехідних процесах пуску асинхронного двигуна.

\section{Література}

1. Минеев А.Р. Моделирование электротехнологических процессов и установок.// А.Р. Минеев, А.И.Коробов, М.Я.Погребисский - М.: Спутник +, 2004. - 124 с.

2. Паранчук Я.С, Головач В.Р. Дослідження оцінок факторів впливу на електричний режим дугової сталеплавильної печі 3 регулятором АРДМ-Т// Науковий вісник Вінницького політехнічного інституту.- 2014.- №3.- с.80-84.

3. Попов А.Е.. Применение частотного управления приводом перемещения электродов в автоматических регуляторах дугових электропечей. // Известия вузов, серия «Электромеханика» - 2005- №2- с.78-80.

4. Лозинський О.Ю., Паранчук Я.С., Паранчук Р.Я., Матіко Ф.Д. Розвиток методів та засобів комп’ютерного моделювання для дослідження електричних режимів дугової сталеплавильної печі. // Науковий вісник національного технічного університету «Харківський політехнічний інститут», серія «Електротехніка і Електромеханіка».2018.-№3.-c.28-37. 


\section{RESEARCH OF THE DYNAMIC PROPERTIES OF THE FREQUENCY- CONTROLLED ELECTRIC DRIVE OF THE MECHANISM OF MOVEMENT OF ELECTRODES OF ELECTRIC ARC FURNACE BY MATHEMATICAL MODELING}

Kuvaiev Viktor, Nezhurin Vadym, Stopkin Vasyl, Kryvytskyi Yevhen

Abstract. Considered literature devoted to the modernization of control systems, controllers and variable-frequency drive mechanism for movement of the electric arc furnace electrodes. The research of current and proposed drives through mathematical modeling. Models of the control system of the electrode mechanism for the basic and proposed variants with scalar and vector control are made in the MATLAB software. Survey on simulation models confirmed that the system provides vector control speed transient time $16 \%$ less than the DC system and a static error is $0 \%$ to $3 \%$. The implementation of the electric drive of the mechanism of movement of electrodes based on the frequency converter with vector control and an induction motor is a promising direction of modernization.

Keywords: FREQUENCY CONVERTER, INDUCTION MOTOR, ARC FURNACE, AUTOMATIC CONTROL SYSTEM, CONTROLLER, TRANSIENTS, MATHEMATICAL MODEL, SCALAR CONTROL, VECTOR CONTROL.

\section{References}

1. Mineev A.R. Modeling of Electrotechnological Processes and Installations. // A.R. Mineev, A.I. Korobov, M.Ya.Pogrebiskiy - M .:Sputnik +, 2004. - 124 p.

2. Paranchuk Y.S., Golovach V.R. Research of the factors of influence on the electric mode of the arc steelmaking furnace with the ARDM-T controller // Scientific Bulletin of Vinnitsa Polytechnic Institute.

3. Popov A.E. Application of frequency control of the drive of moving electrodes in automatic regulators of arc electric furnaces. // News of higher education institutions, series "Electromechanics" - 2005- №2- p.78-80.

4. Lozynsky O.Yu., Paranchuk Y.S., Paranchuk R.Y., Matiko F.D. Development of computer simulation methods and tools for the study of electric modes of an arc furnace. // Scientific Bulletin of the National Technical University "Kharkiv Polytechnic Institute"., series "Electrical Engineering and Electromechanics".- 2018.-№3.-p.28-37. 